\title{
A prospective study between carbamazepine, phenytoin and sodium valproate as monotherapy in previously untreated and recently diagnosed patients with epilepsy
}

\author{
N CALLAGHAN, RA KENNY, B O'NEILL, M CROWLEY, T GOGGIN \\ From the Department of Neurology and Neurology Research Laboratory, Cork Regional Hospital, and \\ Department of Statistics, University College, Cork, Eire
}

SUMMARY One hundred and eighty one patients with previously untreated epilepsy were randomised to sodium valproate, phenytoin or carbamazepine as monotherapy and followed up for a median period which ranged from 14 to 24 months. All three drugs were highly effective in the control of generalised seizures but less effective for partial seizures. Excellent or good control was achieved with therapeutic levels of sodium valproate and carbamazepine, but with subtherapeutic levels of phenytoin.

Prospective studies carried out in recent years have shown that when prescribed as monotherapy with serum anticonvulsant level monitoring, both carbamazepine and phenytoin are effective in the control of patients with generalised and partial seizures. ${ }^{1-4}$ Sodium valproate has been shown to have an anticonvulsant effect in animals and man. ${ }^{5}$ It has been found to be effective when added to other anticonvulsant drugs and as monotherapy. ${ }^{67}$ Sodium valproate, prescribed as monotherapy has been compared with phenytoin ${ }^{89}$ and with ethosuximide. ${ }^{10}$ We report the results of a prospective comparative study carried out between carbamazepine, phenytoin and sodium valproate in previously untreated patients with a recent diagnosis of epilepsy. A preliminary report has already been published. ${ }^{\prime \prime}$

\section{Methods}

Carbamazepine, sodium valproate and phenytoin were prescribed on a randomised basis for previously untreated recently diagnosed patients with generalised or partial seizures who had had a minimum of two seizures over a six months period prior to the referral for assessment.

An electroencephalogram was carried out on all

Address for reprint requests: Dr N Callaghan, Cork Regional Hospital, Wilton, Cork, Eire.

Received 29 February 1984 and in final revised form 30 November 1984. Accepted 10 December 1984 patients, but the classification into generalised or partial seizures was based on a clinical assessment of each patient. Patients were allocated to a generalised seizure group when there was no clinical evidence of a focal association with the seizure. The randomisation procedure which was set up by a statistician was planned as follows. Each patient was allocated three drugs on the basis of a drug of first, second and third preference for each patient. In the randomisation list, carbamazepine was indicated as drug $\mathbf{A}$, sodium valproate as drug $B$ and phenytoin as drug $C$. The randomisation was based on two latin squares in order to balance the order of treatments. The randomisation procedure was not stratified for age, sex or type of seizure. When a patient was selected for the study, the drug of first preferance was selected on a sequential basis from the randomisation list by the secretary in the department of neurology. If a patient did not respond to the initial dose prescribed for that drug the dose was increased and monitored with blood levels. Patients were seen initially one month after the drug was prescribed and at intervals of one to three months thereafter, depending upon response to treatment. Assessments were carried out at an afternoon seizure clinic. At each visit, response to treatment and side effects were documented, and a specimen of blood was taken for estimation of serum anticonvulsant drug levels. The patients were instructed to take the drug twice daily. If the patient did not achieve complete freedom from seizures or at least a greater than $50 \%$ reduction in seizure frequency with high optimal serum levels of the drug of first preference, the dose of that drug was decreased by $200 \mathrm{mg}$ decrements of sodium valproate and carbamazepine and by $100 \mathrm{mg}$ decrements of phenytoin at two weekly intervals, and the drug of second preference allocated from the 
Table 1 Patients with generalised tonic clonic seizures (without focal features)

\begin{tabular}{|c|c|c|c|c|c|c|}
\hline \multirow[t]{2}{*}{ Drug } & \multicolumn{2}{|c|}{ Sex } & \multirow{2}{*}{$\begin{array}{l}\text { Age (yr) } \\
\text { range (mean) }\end{array}$} & \multirow{2}{*}{$\begin{array}{l}\text { Duration of seizures } \\
\text { prior to treatment } \\
\text { months range } \\
\text { (median) }\end{array}$} & \multirow{2}{*}{$\begin{array}{l}\text { Duration of treatment } \\
\text { months range } \\
\text { (median) }\end{array}$} & \multirow{2}{*}{$\begin{array}{l}\text { Total no of seizures } \\
\text { since the onset of attacks } \\
\text { range (median) }\end{array}$} \\
\hline & $M$ & $F$ & & & & \\
\hline $\begin{array}{l}\text { Carbamazepine } \\
\text { Phenytoin } \\
\text { Valproate }\end{array}$ & $\begin{array}{l}13 \\
21 \\
20\end{array}$ & $\begin{array}{l}15 \\
16 \\
17\end{array}$ & $\begin{array}{l}4-72(26) \\
7-69 \\
5-71(26) \\
23)\end{array}$ & $\begin{array}{l}0-132(18) \\
3-156(9) \\
0-120(9)\end{array}$ & $\begin{array}{l}3-44(15) \\
3-42 \\
3-44(18) \\
24)\end{array}$ & $\begin{array}{l}2-1277(4) \\
2-900(4) \\
2-720(3)\end{array}$ \\
\hline
\end{tabular}

Table 2 EEG findings in patients with generalised seizures

\begin{tabular}{llcl}
\hline Drug & $\begin{array}{l}\text { Generalised } \\
\text { discharges }\end{array}$ & $\begin{array}{l}\text { Paroxysmal } \\
\text { slow activity }\end{array}$ & Normal \\
\hline Carbamazepine & 14 & 5 & 9 \\
Phenytoin & 18 & 12 & 7 \\
Valproate & 20 & 8 & 9 \\
\hline
\end{tabular}

randomisation list for that patient was gradually introduced as monotherapy. If satisfactory control did not occur with the drug of second preferance with high optimal serum levels, the drug was gradually withdrawn and the drug of third preferance from the randomisation list for that patient was introduced as monotherapy. Patients were not prescribed combination therapy unless they failed to respond to a trial with the three drugs prescribed as monotherapy.

Carbamazepine was prescribed in a dosage of $600 \mathrm{mg}$ daily for adults and 5-10 mg/kg body weight for children; phenytoin in a dose of $300 \mathrm{mg}$ daily for adults and 5$10 \mathrm{mg} / \mathrm{kg}$ body weight for children; sodium valproate in a dose of $600 \mathrm{mg}$ daily for adults and $5-10 \mathrm{mg} / \mathrm{kg}$ body weight for children. Serum levels of carbamazepine in excess of $30 \mu \mathrm{mol} / \mathrm{l}$ (therapeutic range $15-40 \mu \mathrm{mol} / \mathrm{l}$ ), phenytoin in excess of $70 \mu \mathrm{mol} / 1$ (therapeutic range $40-80$ $\mu \mathrm{mol} / \mathrm{l})$ and sodium valproate in excess of $500 \mu \mathrm{mol} / 1$ (therapeutic range $300-700 \mu \mathrm{mol} / \mathrm{l}$ ) were taken as high optimal blood levels for the three drugs. The dosage prescribed was taken twice daily at $8 \mathrm{am}$ and $1 \mathrm{pm}$. Serum levels of phenytoin and carbamazepine were measured by high performance liquid chromatography, ${ }^{12}$ sodium valproate by gas chromatography. ${ }^{13}$

The response to treatment, based on assessment over a minimum period of three months was classified as follows: Excellent control: Complete freedom from seizures.

Good control: Greater than $50 \%$ reduction in seizure frequency.

Poor control: No response or less than $50 \%$ reduction in seizure frequency.
The classification of seizures is based on the Gastaut 1969 International Classification. ${ }^{14}$

\section{Results}

One hundred and eighty one patients were recruited to the study (ninety five males, eighty six females). One hundred and two patients had generalised seizures while seventy nine patients had partial seizures. Twenty two patients had complex partial seizures with secondary generalised attacks and twenty eigh patiets had complex partial seizures without secondary generalised attacks. Eight patients had simple partial seizures with secondary generalised attacks and twenty one had simple partial seizures withou secondary generalised attacks. In twenty two patients, the complex partial seizures were associated with effective symptomatology, 10 patients with psychomotor symptomatology, 12 patients witk psychosensory symptomatology, and six patiento had cognitive symptomatology. In five patients, the simple partial seizures were associated with autoroㅡㅡㄹ omic symptoms, 14 patients with motor symptoms and 10 patients with sensory symptoms.

\section{Generalised tonic clonic seizures (without focal features)}

The number of patients randomised to the three drugs, the patient's age, duration of seizures and frequency of seizures prior to treatment together with duration of treatment are summarised in table 1 . None of these variables showed a significant difference between the three treatment groups (Snedecor's F and Kruskal Wallis Tests). The EEG findings in patients with generalised seizures are summarised in table 2 and the response to treatment

Table 3 Response in patients with generalised seizures

\begin{tabular}{|c|c|c|c|}
\hline \multirow[t]{2}{*}{ Drug } & \multicolumn{3}{|l|}{ Control } \\
\hline & Excellent & Good & Poor \\
\hline $\begin{array}{l}\text { Phenytoin } \\
\text { Carbamazepine } \\
\text { Valproate } \\
\text { Total }\end{array}$ & 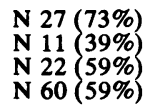 & $\begin{array}{r}3(8 \%) \\
10(36 \%) \\
7(19 \%) \\
20(20 \%)\end{array}$ & $\begin{array}{r}7(19 \%) \\
7(25 \%) \\
8(22 \%) \\
22(21 \%)\end{array}$ \\
\hline
\end{tabular}

Phenytoin $\mathrm{v}$ carbamazepine-excellent control $\mathrm{p}<0.01$. 
Table 4 Patients with partial seizures \pm secondary generalised attacks

\begin{tabular}{|c|c|c|c|c|c|c|}
\hline \multirow[t]{2}{*}{ Drug } & \multicolumn{2}{|c|}{ Sex } & \multirow{2}{*}{$\begin{array}{l}\text { Age (yr) } \\
\text { range (mean) }\end{array}$} & \multirow{2}{*}{$\begin{array}{l}\text { Duration prior to } \\
\text { treatment months } \\
\text { range (median) }\end{array}$} & \multirow{2}{*}{$\begin{array}{l}\text { Duration of treatment } \\
\text { months range } \\
\text { (median) }\end{array}$} & \multirow{2}{*}{$\begin{array}{l}\text { Total no of seizures } \\
\text { since the onset of attacks } \\
\text { range (median) }\end{array}$} \\
\hline & $M$ & $F$ & & & & \\
\hline $\begin{array}{l}\text { Carbamazepine } \\
\text { Phenytoin } \\
\text { Valproate }\end{array}$ & $\begin{array}{l}15 \\
12 \\
14\end{array}$ & $\begin{array}{r}16 \\
9 \\
13\end{array}$ & $\begin{array}{l}8-75(28) \\
7-64(25) \\
6-68(25)\end{array}$ & $\begin{array}{l}0-180(12) \\
6-168(24) \\
3-36(12)\end{array}$ & $\begin{array}{l}3-42(14) \\
3-47(24) \\
3-48(24)\end{array}$ & $\begin{array}{l}2-1095(6) \\
3-300(6) \\
2-732(26)\end{array}$ \\
\hline
\end{tabular}

Table 5 EEG findings in patients with partial seizures

\begin{tabular}{lllll}
\hline Drug & $\begin{array}{l}\text { Focal spike } \\
\text { discharges only }\end{array}$ & $\begin{array}{l}\text { Focal and generalised } \\
\text { spike discharges }\end{array}$ & $\begin{array}{l}\text { Paroxysmal slow } \\
\text { activity }\end{array}$ & Normal \\
\hline Carbamazepine & 10 & 8 & 7 & 6 \\
Phenytoin & 6 & 5 & 6 & 4 \\
Valproate & 8 & 6 & 7 & 6 \\
\hline
\end{tabular}

Table 6 Overall response in patients with partial seizures with or without secondary generalised attacks

\begin{tabular}{llll}
\hline Drug & Control & \\
\cline { 2 - 4 } & Excellent & Good & Poor \\
\hline Phenytoin & N 12 (PC 5 SP 7) (57.1\%) & N 4 (PC 3 SP 1) (19.0\%) & N 5 (PC 4 SP 1) (23.8\%) \\
Carbamazepine & N 11 PC 5 SP 6) (33.5\%) & N 12 (PC 10 SP 2) (38.7\%) & N 8 (PC 6 SP 2) (25.8\%) \\
Valproate & N 12 PC 6 SP 6) (44.4\%) & N 9(PC 7 SP 2) (33.3\%) & N 6 (PC 4 SP 2) (22.2\%) \\
Total & N 35 (44.3\%) & N 25(31.6\%) & N 19(24\%) \\
\hline
\end{tabular}

PC $=$ Partial Complex. SP $=$ Simple Partial.

in table 3. The three drugs improved seizure control. Poor response was similar for all three drugs. However, the ratio for excellent to good control varied between drugs. This difference is statistically significant when phenytoin is compared with carbamazepine for excellent control ( $p<0.01$ Chisquared test).

Partial seizures with or without secondary generalised attacks

The number of patients randomised to the three drugs, the patient's age, duration of seizures and frequency of seizures prior to treatment and duration of treatment are summarised in table 4 . None of these variables showed a significant difference between the treatment groups (Snedecor's F and Kruskal Wallis Tests). The EEG findings in patients with partial seizures are summarised in table 5 and the response to treatment in table 6 . The Chisquared test of significance was used to compare the response of patients with partial seizures in the three groups. No significant differences were found. Subsequently, the analysis was repeated separately for complex partial and simple partial seizures and no differences in response were observed for either variety of partial seizures. Seventy seven percent of patients with secondary generalised attacks achieved excellent or good control. This result compares favourably with patients with primary generalised attacks where $71 \%$ achieved excellent or good control.
Twelve patients dropped out of the study after a period of follow up which ranged from 3 to 9 weeks. These included 10 patients with generalised seizures and two patients with partial seizures. Based on the policy of intention to treat, these patients were analysed as patients with poor control. Five patients with generalised seizures were taking phenytoin, three carbamazepine and two, sodium valproate. One patient with partial seizures was taking phenytoin and one carbamazepine. Ten patients, all with infrequent seizures before entry into the study stopped the drug on their own initiative as they did not wish to continue with treatment. They did not develop any side effects to the drugs. Three patients left the area and could not be contacted.

When a comparison was made between the response in patients with generalised seizures and those with partial seizures, with or without secondary generalised attacks, the overall response was better in patients with generalised attacks $(p<0.05$

Table 7 Control related to seizure frequency and duration of seizures

\begin{tabular}{lcl}
\hline Control & $\begin{array}{l}\text { Seizure frequency } \\
\text { mean } \pm S D\end{array}$ & $\begin{array}{l}\text { Duration of seizures } \\
\text { mean } \pm S D\end{array}$ \\
\hline Excellent & $59 \pm 172$ & $19 \pm 24$ \\
Good & $105 \pm 279$ & $33 \pm 41$ \\
Poor & $221 \pm 306$ & $33 \pm 38$ \\
\hline
\end{tabular}

Control v Frequency $p<0.01$ "Lower frequency"

Control v Duration $\mathrm{p}<0.05$ "Shorter duration". 
Table 8 Further randomisation and response in patients with poor control

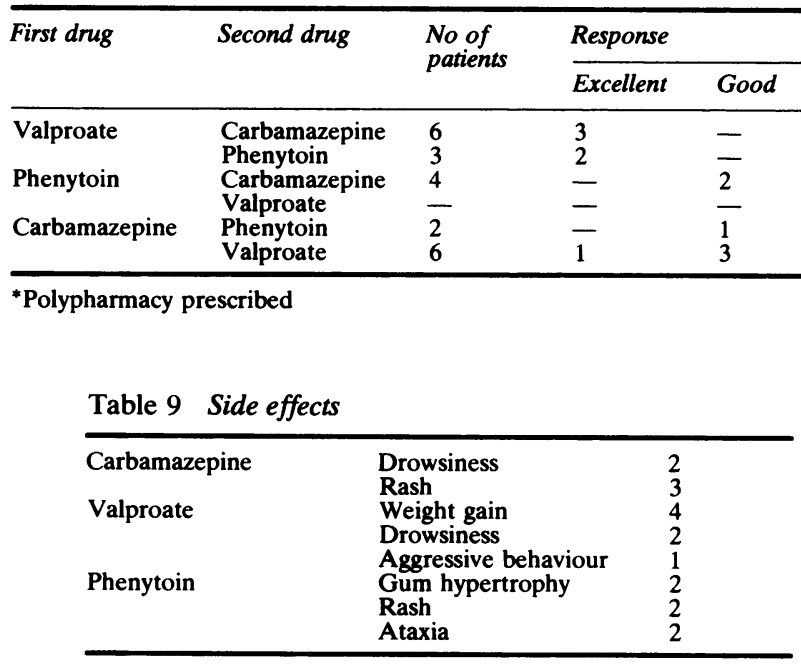

Chi-square test for significance). Overall, patients with a low seizure frequency and shortest duration of epilepsy prior to treatment had the better response $(p<0.01$ and $p<0.05$ respectively, Kruskal Wallis analysis of variance), table 7 .

So far, 21 patients with poor control on the initial drug prescribed haved been rerandomised to a second drug as monotherapy (table 8). Six of these patients achieved excellent control and six patients good control on the second randomised drug. The 12 patients were followed up for periods which ranged from 6 to 36 months. Eight patients continued to have poor control on the second drug and were rerandomised to a third drug. These patients were followed up for a period of 4 to 8 months before they were randomised to the third drug. One achieved good control on the third drug, six continued to have poor control. Combination therapy was prescribed for six patients. They continued to have poor control with combined treatment. One patient has not yet achieved high optimal serum levels of the third drug prescribed and upward dose adjustments are still being carried out. One of the patients who did not respond to phenytoin and who was changed to carbamazepine was withdrawn from the study and not randomised to a third drug. The diagnosis of epilepsy was proved to be incorrect and a diagnosis or pseudoseizures was made. The patient responded to psychiatric treatment.

Eighteen patients developed side effects as summarised in table 9. The increase in weight resulting from sodium valproate did not resolve following restriction of diet and the sodium valproate was dise continued. Two of the patients were prescribed car bamazepine and two phenytoin. Drowsiness occuro red in four patients, two taking carbamazepine an $\overrightarrow{0} \cdot \overrightarrow{0}$ two taking sodium valproate. The drowsiness subso o sided following a reduction in the dose of both drugs. The aggressive behaviour which occurred in one patient taking sodium valproate subsided when carbamazepine was substituted for valproate. The ataxia which occurred with serum levels in excess of $80 \mu \mathrm{mol} / \mathrm{l}$ in two patients taking phenytoin subsided with a reduction in the dosage of the drug. Seizure control in all patients with side effects was in the excellent or good range and was maintained when the anticonvulsant treatment was changed.

Table 10 Mean dose and serum levels $\pm S D$ of anticonvulsant drugs

\begin{tabular}{|c|c|c|c|}
\hline Drug & Control & $\begin{array}{l}\text { Mean dose } \pm S D \\
m g / k g \text { body weight }\end{array}$ & $\begin{array}{l}\text { Mean levels } \pm S D \\
\mu m o l / l\end{array}$ \\
\hline Valproate by control & $\begin{array}{l}\text { All patients } \\
\text { Excellent } \\
\text { Good } \\
\text { Poor }\end{array}$ & $\begin{array}{l}15 \cdot 6 \pm 12.1 \\
12.7 \pm 10 \cdot 0 \\
19 \cdot 5 \pm 15 \cdot 0 \\
17.5 \pm 11.9\end{array}$ & $\begin{array}{l}433 \cdot 8 \pm 214 \cdot 1 \\
364 \cdot 3 \pm 178 \cdot 4 \\
528 \cdot 6 \pm 207 \cdot 6\end{array}$ \\
\hline Carbamazepine by control & $\begin{array}{l}\text { All patients } \\
\text { Excellent } \\
\text { Good } \\
\text { Poor }\end{array}$ & $\begin{aligned} 17 \cdot 5 & \pm 11 \cdot 9 \\
10 \cdot 9 & \pm 6 \cdot 9 \\
8 \cdot 6 & \pm 3 \cdot 1 \\
10 \cdot 2 & \pm 6 \cdot 6 \\
17 \cdot 1 & \pm 9 \cdot 4\end{aligned}$ & $\begin{array}{c}521.8 \pm 185.6 \\
28.7 \pm 11.5 \\
25.7 \pm 10.2 \\
30.5 \pm 12.2 \\
34.3 \pm 10.9\end{array}$ \\
\hline Phenytoin by control & $\begin{array}{l}\text { All patients } \\
\text { Excellent } \\
\text { Good } \\
\text { Poor }\end{array}$ & $\begin{array}{l}5 \cdot 4 \pm 1 \cdot 8 \\
4 \cdot 9-1 \cdot 7 \\
5 \cdot 5 \pm 2 \cdot 1 \\
6 \cdot 9 \pm 1 \cdot 4\end{array}$ & $\begin{array}{l}35.9 \pm 28.0 \\
26.9 \pm 10.7 \\
28.5 \pm 19.7 \\
73.5 \pm 36.1\end{array}$ \\
\hline
\end{tabular}


Serum drug levels

Drug levels and drug dosage related to seizure control for the three drugs are shown in table 10. Excellent and good control with sodium valproate or carbamazepine was associated with therapeutic blood levels for both drugs. However, excellent or good control in patients taking phenytoin was achieved with sub-therapeutic blood levels. The highest levels for carbamazepine and phenytoin occurred in patients with poor control.

\section{Discontinuation of treatment}

So far, treatment has been discontinued in 26 patients, eight taking carbamazepine, seven taking valproate and 11 phenytoin. Four patients have relapsed, one taking carbamazepine, two taking phenytoin and one taking sodium valproate.

\section{Discussion}

A number of studies based on crossover designs have been carried out to compare carbamazepine with phenytoin in patients with generalised and partial seizures. In these studies both drugs have been found to be effective in the control of generalised ${ }^{1516}$ and partial seizures. ${ }^{17} 18$ The results of all these studies are based on short follow up periods. Shakir et $a^{819}$ compared sodium valproate with phenytoin in one group of patients and with carbamazepine in a different group. In the carbamazepine group the findings suggested that both carbamazepine and valproate were equally effective in the control of generalised and partial seizures. In the phenytoin group, the number of patients studied was too small to make a valid comparison, but the findings did suggest that partial seizures were helped by sodium valproate. In this study, all three drugs were found to be effective for the control of both generalised and partial seizures with a better response in patients with generalised attacks. Turnbull et $a^{920}$ carried out a prospective study in previously untreated patients to compare phenytoin with sodium valproate. Both drugs were found to be effective for the control of both generalised and partial seizures, but less effective in the control of partial attacks. In previous studies, ${ }^{67}$ the response to sodium valproate of patients with complex partial seizures or simple partial seizures has been poor, but we could not find any difference between the three drugs when a comparison was made between sodium valproate, carbamazepine and phenytoin for the control of simple partial seizures or complex partial seizures with or without secondary generalised attacks.

Bruni $e t a^{21}$ studied the efficacy of valproic acid for complex partial seizures. Fifty per cent of patients initially responded and $20 \%$ obtained long- term benefit. In the patients who did not obtain longterm benefit, seizure frequency increased following initial improvement. This appeared to be related to seizure frequency prior to treatment, as most patients who deteriorated had a high seizure frequency before treatment was given. We have shown that all three drugs were less effective in the control of patients with generalised or partial seizures with the highest seizure frequency and the longest duration of seizures prior to commencing treatment. These findings would be in keeping with the observations of Rodin ${ }^{22}$ for patients with chronic epilepsy.

The results for phenytoin and carbamazepine are in keeping with previous studies of both drugs used as monotherapy. ${ }^{1-4}$ In these studies, both drugs were found to be effective in generalised seizures and less effective in patients with partial seizures. Sodium valproate has been found to be effective when prescribed as monotherapy ${ }^{7}$ and when compared with ethosuximide in patients with typical absence seizures ${ }^{10}$ both drugs were found to be equally effective.

So far, a total of 21 patients have failed to respond to the first drug prescribed as monotherapy, despite high levels of the drugs. It has been shown that satisfactory control can be obtained in many patients with monotherapy, monitored with blood levels, ${ }^{1-3}$ and that reduction in polypharmacy can result in improved seizure control. ${ }^{323}{ }_{24}$ However, when a patient fails to respond to the first drug prescribed as monotherapy, there is still a tendency to prescribe multiple drugs. We have shown that by substituting an alternative drug as monotherapy for patients who have failed to respond to the first drug prescribed, and a third drug as monotherapy when patients fail to respond to the second drug, it was possible to restrict polypharmacy to six patients.

When mean blood levels, based on levels measured on a fixed dose of the drug were evaluated, it was found that with carbamazepine, excellent or good control was achieved with levels within the therapeutic range, while a similar degree of control with phenytoin was achieved with sub-therapeutic levels of the drug. High optimal levels occurred in patients taking carbamazepine or phenytoin in association with poor control and in patients taking valproate in association with good or poor control. The lowest blood levels for all three drugs were found in patients with excellent control, higher levels occurring in patients with good or poor control. This was based on the tendency for the clinician to increase the dose in this group of patients in an attempt to achieve better control.

There was no significant difference between the overall incidence of side effects between the three 
drugs and with the exception of patients who developed ataxia with toxic levels of phenytoin, we could not detect any correlation between side effects and serum blood levels. There was an association between dosage and drowsiness for carbamazepine and valproate, with improvement in the drowsiness following a reduction in drug dosage. Aggressive behaviour has already been described in children taking sodium valproate ${ }^{25}$ but this side effect occurred more frequently when the drug was used in combination with other antiepileptic drugs, in particular, phenobarbitone.

In conclusion, our results show that sodium valproate, carbamazepine and phenytoin are effective in the control of generalised and partial seizures, and that all three drugs can be prescribed as an anticonvulsant of first choice. Irrespective of the drug prescribed, partial seizures were less responsive to treatment.

This work was supported by grants from Labaz, Geigy, and Warner-Lambert. The high pressure liquid chromatograph was purchased by the Munster Epilepsy Research Fund. We are grateful to Miss Heather O' Donovan for typing the manuscript.

\section{References}

' Reynolds EH, Chadwick DW, Galbraith AW. One drug (phenytoin) for the treatment of epilepsy. Lancet 1976; 1:923-6.

${ }^{2}$ Shorvon SD, Chadwick DW, Galbraith AW, Reynolds EH. One drug for epilepsy. Br Med J 1978;1:474-6.

${ }^{3}$ Callaghan N, O'Callaghan M, Duggan B, Feely M. Carbamazepine as a single drug for the treatment of epilepsy. J Neurol Neurosurg Psychiatry 1978;41:907-12.

${ }^{4}$ Feely M, Duggan B, O'Callaghan M, Callaghan N. The therapeutic range for phenytoin: a reappraisal. Ir $J$ Med Sci 1979;2:44-9.

${ }^{5}$ Simon D, Penry JK. Sodion D-N-Propylacetate (DPA) in the treatment of epilepsy. Epilepsia 1975;16:45973.

6 Jeavons PM, Clarke JE. Sodium valproate in the treatment of epilepsy. Br Med J 1974;2:584-6.

7 Covanis A, Gupta AK, Jeavons PM. Sodium valproate: monotherapy and polytherapy. Epilepsia 1982;23:693-720.

${ }^{8}$ Shakir RA, Johnson RH, Lambie DG, Melville ID, Nanda RN. Comparison of sodium valproate and phenytoin as single drug treatment in epilepsy. Epilepsia 1981;22:27-33.

ฯ Turnbull DM, Rawlings MD, Weightman D, Chadwick DW. A comparison of phenytoin and valproate in previously untreated adult epileptic patients. J Neurol
Neurosurg Psychiatry 1982;45:55-9.

${ }^{10}$ Callaghan N, O'Hare J, O' Driscoll D, O'Neill B, Daly M. A comparative study of ethosuximide and sodium valproate in the treatment of typical absence seizures (petit mal). Dev Med Child Neurol 1982;24:830-6.

" Callaghan N, Kenny RA, O'Neill B, Crowley M, Goggin T. A comparative study between carbamazepine, phenytoin and sodium valproate as monotherapy in previously untreated and recently diagnosed patients with epilepsy. A preliminary communication. $\mathbf{B r} \mathbf{J}$ Clin Pract A symposium supplement. 1983;27:7-9.

12 Kabra K, Pokar M, Stafford BE, Matron LJ. Simultaneous measurement of phenobarbital, phenytoin, primidone, ethosuximide and carbamazepine in serum by high pressure liquid chromatography. Clin Chem 1977;23: 1284 .

${ }^{13}$ Chard CR. A simple method for the determination of Epilim in serum. In: Leggs NJ, ed. Clinical and Pharmacological Aspects of Sodium Valproate (Epilim) in the Treatment of Epilepsy. Tunbridge Wells: MCS Consultants, 1976:89.

${ }^{14}$ Gastaut H. Classification of the epilepsy. Epilepsia Supplement 1969;10:514.

${ }^{15}$ Rajotte P, Jilek W, Jilek L, et al. Proprietes antiepileptiques ets psychotropes de la carbamazepine (tegretol). Union Med Can 1967;96:1200-6.

${ }^{16}$ Kosteligjanetz M, Christiansen J, Dam AM, et al. Carbamazepine vs Phenytoin. Arch Neurol 1979;36:224.

17 Troupin AL, Ojemann LM, Halpern L, et al Carbamazepine-a double-blind comparison witk phenytoin. Neurology (Minneap) 1977;27:511-9.

${ }^{18}$ Simonsen N, Zander Olsen P, Kuhl V, Lund M, Wen delboe J. A comparative controlled study between. carbamazepine and diphenylhydantoin inD psychomotor epilepsy. Epilepsia 1976;17:169-76.

${ }^{19}$ Shakir RA. Sodium valproate, phenytoin and carbamazepine as sole anticonvulsants. In: The place of sodium valproate in the treatment of epilepsy. $R$ Soc Med International Congress and Symposium Series. London: Academic Press, 1980;30:7-16.

20 Turnbull DM, Rawlings MW, Weightman D, Chadwick DW. A longterm comparative study between phenytoin and valproate in adult onset epilepsy. $\mathrm{Br} J \mathrm{Clin}$ Pract. Symposium supplement 27 1983:3-5.

${ }^{21}$ Bruni J, Albright P. Valproic acid as therapy for complex partial seizures: its efficacy and toxic effects. Arch Neurol 1983;40:135-7.

22 Rodin EA. The Prognosis of Patients with Epilepsy. Springfield: Thomas, 1968.

${ }^{23}$ Reynolds EH, Shorvon SD. Monotherapy and polytherapy for epilepsy. Epilepsia 1981;22:1-10.

${ }^{24}$ Callaghan $\mathbf{N}$, O'Dwyer $\mathbf{R}$, Keating J. Unnecessary polypharmacy in patients with frequent seizures. Acta Neurol Scand 1984;69:15-19.

${ }^{25}$ Herranz JL, Arteaga Rosa, Armijo Juan A. Side effects of sodium valproate in monotherapy, controlled by plasma levels. A study of 88 paediatric patients. Epilepsia 1982;23:203-14. 